\title{
Spray nozzle selection contributes to improved postemergence herbicide crabgrass control in turfgrass
}

\author{
Edward Nangle, ${ }^{1}$ Zane Raudenbush, ${ }^{1}$ Tyler Morris, ${ }^{1}$ Michael Fidanza ${ }^{2}$ \\ ${ }^{1}$ Ohio State University, Agricultural Technical Institute, Wooster, OH; ${ }^{2}$ Pennsylvania State University, \\ Reading, PA, USA
}

Highlights

- In turfgrass sites with low crabgrass pressure, one postemergence application of quinclorac herbicide could potentially achieve acceptable control with spray nozzles that produce spray droplets ranging from ultra coarse (>650 $\mu \mathrm{m})$ to fine (145-225 $\mu \mathrm{m})$.

- In turfgrass sites with heavy crabgrass population and pressure, one postemergence application of quinclorac herbicide is best optimized with spray nozzles that produce spray droplets ranging from very coarse (401-500 $\mu \mathrm{m})$ to medium $(226-325 \mu \mathrm{m})$.

- Overall, turfgrass management practitioners should avoid using spray nozzles that produce a hollow cone spray pattern with ultra coarse $(>650 \mu \mathrm{m})$ spray droplets which can result in poor or irregular herbicide coverage, or fine (145-225 $\mu \mathrm{m})$ spray droplets which are subject to potential drift and possible negative off-target effects.

- Overall, in an effort to reduce herbicide use for postemergence crabgrass control, a single quinclorac herbicide application could be properly timed and optimized with nozzles that produce spray droplets ranging from very coarse (401-500 $\mu \mathrm{m})$ to medium (226-325 $\mu \mathrm{m})$ in size, however, future research should consider cultural practices that would further optimize and also reduce herbicide applications.

\begin{abstract}
For optimum postemergence crabgrass (Digitaria spp.) control, a single quinclorac herbicide application could be properly timed and delivered with spray nozzles that produce spray droplets ranging from very coarse $(401-500 \mu \mathrm{m})$ to medium $(226-$ $325 \mu \mathrm{m})$ in size to maximize target coverage and minimize the potential for drift. Crabgrass is an invasive annual grass weed of cool-season turfgrass maintain as lawns, golf courses, and sports pitches. Postemergence herbicide applications for crabgrass control in turfgrass swards often rely on repeated applications for effective control. Optimizing postemergence crabgrass applications can reduce pesticide inputs and contribute to sustainable turfgrass management practices. Two field studies evaluating crabgrass control were conducted in 2020 in a mixed stand of Kentucky bluegrass (Poa pratensis L.) with perennial ryegrass
\end{abstract}

Correspondence: Michael Fidanza, Pennsylvania State University, Berks Campus, Reading, PA, 19610, USA. E-mail: maf100@psu.edu

Key words: Application; crabgrass; Digitaria; droplet; efficacy; herbicide; lawn; nozzles; postemergence; spray; turf; turfgrass.

Received for publication: 23 February 2021.

Revision received: 22 June 2021.

Accepted for publication: 25 June 2021.

(C) Copyright: the Author(s), 2021

Licensee PAGEPress, Italy

Italian Journal of Agronomy 2021; 16:1846

doi:10.4081/ija.2021.1846

This article is distributed under the terms of the Creative Commons Attribution Noncommercial License (by-nc 4.0) which permits any noncommercial use, distribution, and reproduction in any medium, provided the original author(s) and source are credited.
(Lolium perenne L.) in Ohio (USA) and in perennial ryegrass in Pennsylvania (USA). Both sites have histories of natural crabgrass [Digitaria sanguinalis (L.) Scop.] infestation. A postemergence herbicide, quinclorac, was applied at the product label rate and tank-mixed with methylated seed oil at the crabgrass plant stage of three-leaf to one tiller. Different spray nozzles were selected to deliver the following spray droplet classifications and sizes at 275 $\mathrm{kPa}$ : Delavan Raindrop 1/4, ultra coarse $(>650 \mu \mathrm{m})$; TurfJet 1/4TTJO4, extremely coarse (501-650 $\mu \mathrm{m})$; Air Induction AA8004 or XRTeeJet 8015 , very coarse $(401-500 \mu \mathrm{m})$; XR TeeJet 8008 or GreenLeaf TDAD04, coarse $(326-400 \mu \mathrm{m})$; XR TeeJet 8004, medium (226-325 $\mu \mathrm{m})$; and XRTeeJet 8003 fine (145-225 $\mu \mathrm{m})$. Crabgrass pressure was low in Ohio, and herbicide efficacy at 60 days after treatment was considered acceptable when applied from all spray nozzles that produced spray droplet sizes ranging from ultra coarse to fine. Crabgrass pressure was severe in Pennsylvania, and herbicide efficacy at 60 DAT was considered marginally acceptable when applied from spray nozzles that produced spray droplet sizes ranging from very coarse to medium. Future research should consider cultural practices that would be complementary to postemergence herbicide applications with the goal to reduce pesticide use further and minimize any potential environmental impacts related to spray drift.

\section{Introduction}

Crabgrass (Digitaria spp.) is considered the most invasive and troublesome weed of cool-season lawns and managed recreational turfgrass swards (Dernoeden et al., 2003; Watschke et al., 2013). Crabgrass is a warm-season annual grass species that first germinates and emerges in the spring, but emergence can continue into the summer (Fidanza et al., 1996). In mid-summer, crabgrass becomes more competitive and can aggressively spread throughout a cool-season turfgrass stand. Turfgrass professionals apply preemergence herbicides as a commonly used strategy to provide 
season-long suppression of crabgrass (Watschke et al., 2013). However, an inaccurately timed application, incorrect application rate, unseasonably wet weather, or extended crabgrass germination and emergence periods may reduce the efficacy of preemergence herbicides (Martin and Sullivan, 1996; Fidanza et al., 1996; Brosnan et al., 2014). When poor crabgrass control is observed from a preemergence herbicide application, a postemergence herbicide application is warranted (McCarty et al., 2005).

In the USA, quinclorac (3,7-dichloro-8-quinolinecarboxylic acid) herbicide is used for postemergence crabgrass management in turf maintained as lawns, golf courses, and sports pitches (Chism and Bingham, 1991; Johnson, 1994; McCarty et al., 2005). Quinclorac is classified as a group 4 herbicide and is a quinolone carboxylic acid that acts as an auxin mimic at the site of the cell wall synthesis in roots and inhibits the development of cellulose by $70 \%$ and other cell wall components by 50 to $60 \%$ (Koo et al., 1997; Grossman, 1998; Senseman, 2007). Quinclorac acts quickly with peak concentration measured in roots after $6 \mathrm{H}$ and foliage after $8 \mathrm{H}$ (Berghaus and Wuerzer, 1989; Koo et al., 1997). Quinclorac uptake is accelerated by various climatic conditions such as high light intensity or sufficiently moist soil (Grossman, 1998). Susceptible plants treated with quinclorac experience rapid inhibition of shoot growth and development of chlorotic juvenile tissue followed by necrosis of the shoots (Koo et al., 1991; Grossmann and Kwiatkowski, 1993; Koo et al., 1997). In practice, quinclorac in the form of a commercially formulated herbicide is tank-mixed with methylated seed oil to improve efficacy (McCarty et al., 2005). The addition of spray adjuvants such as surfactants and oils results in greater uptake of quinclorac due to enhanced penetration into the leaf and maintaining the quinclorac in solution rather than crystalizing on the leaf surface (Steinke and Stier, 2002; Woznica et al., 2003).

Recent advances with pesticide application technology include spray nozzles (i.e., spray tips) that improve the delivery of foliarapplied herbicides (Creech et al., 2015; Contiero et al., 2016), and also utilize correct spray nozzles and techniques to reduce the spray drift to non-target sites (Kalsing et al., 2018; Grella et al., 2020). The spray nozzle produces a spray pattern which contains spray droplets in various sizes depending on the nozzle type (Lake, 1977; ASABE, 2009). A larger spray droplet size translates to poorer coverage (i.e., less droplets per unit area) but better at drift reduction as compared to smaller spray droplets that facilitate bet- ter coverage (i.e., more droplets per unit area) but are more prone to drift off-target (ASABE, 2009; Fidanza et al., 2009a; Fidanza et al., 2009b; Kaminski and Fidanza, 2009; Stainier et al., 2006; Creech et al., 2015).

The spray droplet sizes are based on the manufacturer's laboratory analysis and specifications (ASABE, 2009; Creech et al., 2015). Since all spray nozzles produce a range of droplet sizes within their spray pattern, the volume mean diameter (VMD) value represents $50 \%$ of the total volume of liquid spray comprised of droplets within diameters larger than the median value and $50 \%$ smaller than the median value (ASABE, 2009). The manufacturer provides droplet size information for various nozzle types at various application pressures (ASABE, 2009).

If quinclorac efficacy of a single postemergence crabgrass application could be improved using a specific spray nozzle, this could negate the need for repeated postemergence applications (Fidanza et al., 1996; Dernoeden et al., 2003; McCarty et al., 2005; Watschke et al., 2013). This would also help reduce any potential for environmental contamination, to aid turfgrass managers in reducing herbicide applications and overall weed control costs, and potentially reduce overall pesticide usage. However, the effect of the spray nozzle has not been evaluated for the use of quinclorac on postemergence control of crabgrass. Therefore, the objective of this field study was to evaluate the efficacy of various spray nozzles which produce various spray droplet sizes on a single quinclorac herbicide application for postemergence control of crabgrass in cool-season turfgrass.

\section{Materials and methods}

A field study was conducted at two locations, in Hinckley, Ohio (USA) and Reading, Pennsylvania (USA). One postemergence herbicide treatment was applied at both sites when most of the crabgrass plants were at the one tiller plant growth stage. At both locations, quinclorac (Drive $\mathrm{XLR} 8^{\circledR}$; water-based formulation; $180 \mathrm{~g}$ ai $\cdot \mathrm{L}^{-1}$; BASF, Research Triangle Park, NC, USA) was applied at the product label rate of $9.16 \mathrm{~kg}$ a.i. $\mathrm{ha}^{-1}$ tank-mixed with $1.75 \mathrm{~L}$ methylated seed oil $\cdot \mathrm{ha}^{-1}$. Treatments consisted of the herbicide delivered through eight different spray nozzles, which produced different spray droplet sizes classified from fine to ultra coarse (Table 1).

Table 1. Spray nozzle, spray pattern, spray droplet size classification, and spray droplet size evaluated in the field studies in Wooster, Ohio, USA, and Reading, Pennsylvania, USA, 2020.

\begin{tabular}{lcccc} 
Spray nozwle & Spray pattern & Spray droplet classification & $\begin{array}{c}\text { Spray droplet size } \\
\text { Volume mean diameter (1um) }\end{array}$ \\
Delavan Raindrop 1/4 & Hollow cone & UC & Ultra-coarse & $>650$ \\
TurfJet 1/4TTJ04 & Flat fan & EC & Extremely coarse & $501-650$ \\
\hline Air Induction AA8004 & Flat fan & VC & Very coarse & $401-500$ \\
XR TeeJet 8015 & Flat fan & VC & Very coarse & $401-500$ \\
\hline XR TeeJet 8008 & Flat fan & C & Coarse & $326-400$ \\
GreenLeaf TDAD04 & Dual flat fan & C & Coarse & $326-400$ \\
\hline XR TeeJet 8004 & Flat fan & M & Medium & $226-325$ \\
XR TeeJet 8003 & Flat fan & F & Fine & $145-225$ \\
\hline
\end{tabular}

*The volume mean diameter value represents $50 \%$ of the total volume of liquid spray comprised of droplets within diameters larger than the median value and $50 \%$ smaller than the median value for all nozzle types listed at $275 \mathrm{kPa}$ application pressure. 


\section{Ohio}

The site was located on a mixed stand of unknown cultivars of Kentucky bluegrass (Poa pratensis L.), and perennial ryegrass (Lolium perenne L.) maintained as a golf course fairway (Hinckley Hills Golf Course; Hinckley, Ohio, USA). The turf was maintained at the height of $25 \mathrm{~mm}$ and typically mowed three times per week during the growing season with a reel mower, and clippings were not removed. The native clay soil rootzone had a $\mathrm{pH}$ of 6.4 with $4.4 \%$ organic matter. The site has a history of crabgrass infestation. No fertilizer or pesticides (i.e., insecticides or fungicides) were applied prior to or during the study period.

Plot sizes were $0.9 \times 1.5 \mathrm{~m}$ and organized in a randomized complete block design with four replications. All treatments were applied from a $\mathrm{CO}_{2}$-powered backpack sprayer (Bellsprayers Inc., Opelousas, LA, USA) at $275 \mathrm{kPa}$, from a single handheld nozzle boom through a water-carrier volume of $407 \mathrm{~L} \cdot \mathrm{ha}^{-1}$ to evenly cover the entire plot at $4.8 \mathrm{~km} \cdot \mathrm{H}^{-1}$ groundspeed. The sprayer was calibrated for each nozzle to deliver $407 \mathrm{~L}$ water $\cdot \mathrm{ha}^{-1}$ before the initiation of the study.

Treatments were applied on $24^{\text {th }}$ June 2020 when average crabgrass was visually determined to be at the three to four-leaf stage. The average plot area covered with crabgrass prior to treatment applications was $24 \%$ based on visual assessment. At a $38 \mathrm{~mm}$ depth, the soil temperature was measured at $1100 \mathrm{H}$ and averaged $18.1 \mathrm{oC}$ with average soil moisture of $23.8 \%$ (Field Scout 300 TDR Soil Moisture Meter; Spectrum Technologies, Aurora, IL, USA) across the study site. On $1^{\text {st }}$ July 2020, a granular application of prodiamine (Barricade ${ }^{\circledR}$ formulated as a granular product with $0.48 \%$ active ingredient; The Andersons Inc., Maumee OH, USA) was applied to the entire study site at the product label rate of 1110 $\mathrm{g}$ a.i. $\mathrm{ha}^{-1}$ followed by irrigation to a depth of $7 \mathrm{~mm}$ to prevent further crabgrass germination and emergence.

\section{Pennsylvania}

The study site was located on mature perennial ryegrass (Lolium perenne L., 'Double Eagle' blend) stand, maintained as a residential lawn, with a history of natural crabgrass emergence, at the Center for the Agricultural Science and a Sustainable Environment (Pennsylvania State University, Berks Campus, Reading, PA, USA). The root zone was a loam soil with $\mathrm{pH}=6.1$ and $3.6 \%$ organic matter. The site received $49 \mathrm{~kg} \mathrm{~N} \cdot \mathrm{ha}^{-1}$ from granular urea $\left(46 \mathrm{~N}-0 \mathrm{P}_{2} \mathrm{O}_{5}-0 \mathrm{~K}_{2} \mathrm{O}\right)$ on $5^{\text {th }}$ May 2020 , with no other fertilizer or pesticide inputs prior to or during the study period. The turf was mowed with a rotary mower once or twice per week at the height of $64 \mathrm{~mm}$, and clippings were not removed.

The individual plot size was $1 \times 1.5 \mathrm{~m}$, and treatments were arranged as a randomized complete block design with four replications. All treatments were applied from a $\mathrm{CO}_{2}$-powered backpack sprayer (Bellsprayers Inc., Opelousas, LA, USA) at $275 \mathrm{kPa}$, from a handheld single nozzle boom, and in a water-carrier volume of $407 \mathrm{~L} \cdot \mathrm{ha}^{-1}$ to evenly cover the entire plot at $4.8 \mathrm{~km} \cdot \mathrm{H}^{-1}$ groundspeed. Before the start of the study, the sprayer was calibrated for each nozzle to deliver $407 \mathrm{~L}$ water $\cdot \mathrm{ha}^{-1}$. All treatments were applied on $25^{\text {th }}$ June 2020 . The average crabgrass growth stage was visually determined to be four-leaf to one tiller stage, and the average crabgrass population was $37 \%$ plot area covered. At approximately $1000 \mathrm{H}$ on $25^{\text {th }}$ June 2020 , the average soil temperature across the study area at the $38 \mathrm{~cm}$ depth was $21.0^{\circ} \mathrm{C}$, and the average volumetric water content was $23.2 \%$ (Field Scout 300 TDR Soil Moisture Meter; Spectrum Technologies, Aurora, IL, USA). The study site was mowed on $22^{\text {nd }}$ July 2020, which was three days prior to treatment applications.
In order to suppress potential crabgrass seedlings from germinating and emerging after quinclorac treatments were applied, the entire study site received an application of pendimethalin (Pendulum AquaCap ${ }^{\circledR}$ formulated as $455 \mathrm{~g}$ ai $\cdot \mathrm{L}^{-1}$; BASF, Research Triangle Park, NC, USA) preemergence herbicide on $28^{\text {th }}$ June 2020. Pendimethalin herbicide was applied to the entire study site at the product label rate of $645 \mathrm{~g}$ a.i. $\cdot \mathrm{ha}^{-1}$. The entire site was irrigated with approximately $7 \mathrm{~mm}$ water immediately following application to rinse the herbicide into the upper rootzone.

\section{Data collection and data analysis}

Plots were visually evaluated for percent plot area covered with crabgrass approximately every seven to ten days from $24^{\text {th }}$ June to $23^{\text {rd }}$ August 2020 in Ohio and from $25^{\text {th }}$ June to $24^{\text {th }}$ August 2020 in Pennsylvania. The end of the study in Ohio and Pennsylvania represented 60 DAT (days after treatment), and therefore only initial (0 DAT) and end 60 (DAT) data are presented. Plot area covered with crabgrass at $\leq 10 \%$ is considered acceptable, 11 to $25 \%$ is marginally acceptable, and $\geq 26 \%$ is not acceptable (Dernoeden et al., 2003; Watschke et al., 2013). At both locations, percent control per plot was determined by comparing the initial crabgrass plot area covered at the start of the study to the final crabgrass plot area covered at the end of the study, using the following formula:

$\frac{\text { Percent plot area cover in untreated plot }- \text { Percent plot area cover in treated plot }}{\text { Percent plot area cover in untreated plot }} \times 100$

Crabgrass control at $\geq 90 \%$ is considered acceptable, 75 to $89 \%$ is marginally acceptable, and $\leq 74 \%$ is not acceptable (Dernoeden et al., 2003; Watschke et al., 2013). All data were analysed using Agricultural Research Manager (GDM Solutions, Brookings, South Dakota, USA), and treatment means were compared using Fisher's protected least significance difference test at $\mathrm{P} \leq 0.05$ (Mead et al., 2003).

\section{Results}

Examination of analysis of variance of data revealed a nonsignificant replication effect at Ohio $(\mathrm{P}<0.0801)$ and Pennsylvania $(\mathrm{P}<0.1906)$ at the start of the study, thus indicating a uniform crabgrass population among all four replications at both locations (Table 2). At 60 days after treatment (DAT), analysis of variance for replication effect was not significant (ranging from $\mathrm{P}<0.0841$ to $\mathrm{P}<0.9327$ ) at both locations, but treatment effect was significant $(\mathrm{P}<0.001)$ at both locations (Table 2).

\section{Ohio}

At the start of the study on $24^{\text {th }}$ June 2020 , the average plot area covered with crabgrass in the untreated plots was $28 \%$ and progressed to $41 \%$ by $24^{\text {th }}$ August 2020 (60 DAT) (Table 3). This amount of crabgrass emergence was considered to be of low $(<50 \%$ plot area covered) pressure.

At 60 DAT, all plots treated with herbicide had crabgrass coverage ranging from $<1$ to $7 \%$ plot area covered, which was significantly lower than crabgrass observed in the untreated plots of $41 \%$ (Table 3 ). With all herbicide-treated plots, no sig- 
nificant differences were observed among all herbicide-spray nozzle treatments (Table 3 ).

At 60 DAT, best crabgrass control (95 to 98\%) was observed in plots treated from nozzles that produced ultra coarse, very coarse, coarse, medium, or fine spray droplets, but the lowest control $(83 \%)$ was observed in plots treated from nozzles that produced from extremely coarse spray droplets (Table 3 ). No significant differences were detected, however, in plots treated from nozzles that produced ultra coarse, extremely coarse, or coarse (dual flat fan nozzle only) spray droplets (Table 3). Thus, no turfgrass injury or phytotoxicity was observed at any time from the herbicide application.

\section{Pennsylvania}

At the initiation of the study on $25^{\text {th }}$ June 2020 , the average plot area covered with crabgrass in the untreated plots was $40 \%$, which progressed to $84 \%$ by $24^{\text {th }}$ August 2020 (60 DAT), thus illustrating the aggressive and invasive nature of the heavy $(>50 \%$ plot area covered) crabgrass population at this study site (Table 3). At 60 DAT, all plots treated with herbicide had 12 to $35 \%$ plot area covered with crabgrass, which was significantly less than crabgrass observed in the untreated plots with $84 \%$ (Table 3 ).

At 60 DAT, the lowest crabgrass coverage was observed in plots treated from nozzles that produced very coarse spray droplets at 12 to $17 \%$ (Table 3). Plots treated from nozzles that produced

Table 2. Analysis of variance for postemergence herbicide crabgrass (Digitaria sp.) efficacy data as influenced by spray nozzles from field studies in Wooster, Ohio, USA, and Reading, Pennsylvania, USA, 2020.

\begin{tabular}{|c|c|c|c|c|c|c|c|}
\hline \multirow[b]{2}{*}{ Source of variation ${ }^{\wedge}$} & \multirow[b]{2}{*}{ Degrees of freedom } & \multicolumn{2}{|c|}{$\begin{array}{c}24 \text { Jun (0 DAT) } \\
\% \text { plot area covered }\end{array}$} & \multicolumn{2}{|c|}{$\begin{array}{r}23 \text { Aug ( } 60 \text { DAT) } \\
\% \text { plot area covered }\end{array}$} & \multicolumn{2}{|c|}{$\begin{array}{l}23 \text { Aug (60 DAT) } \\
\% \text { control }^{\#}\end{array}$} \\
\hline & & Mean square & Prob (F) & Mean square & Prob (F) & Mean square & Prob (F) \\
\hline Replicate & 3 & 1194.707 & 0.0801 & 10.651 & 0.9327 & 115.539 & 0.1719 \\
\hline Treatment & 17 & 176.407 & 0.0643 & 603.48 & 0.0001 & 40239.325 & 0.0001 \\
\hline Error & 51 & 90.503 & & 73.649 & & 66.671 & \\
\hline \multirow[b]{2}{*}{ Source of variation ${ }^{\wedge}$} & & $\begin{array}{l}25 \text { Jun } \\
\% \text { plot are }\end{array}$ & $\begin{array}{l}\text { ennsylvanis } \\
\text { II) } \\
\text { ered }\end{array}$ & $\begin{array}{l}24 \text { Aug } \\
\% \text { plot area }\end{array}$ & $\begin{array}{l}\text { DAT) } \\
\text { vered }\end{array}$ & $\begin{aligned} 24 \mathrm{Au} \\
\% \mathrm{C}\end{aligned}$ & $\begin{array}{l}\text { DAT) } \\
l^{*}\end{array}$ \\
\hline & Degrees of freedom & Mean square & Prob (F) & Mean square & Prob (F) & Mean square & Prob (F) \\
\hline Replicate & 3 & 0.257 & 0.1906 & 16.184 & 0.9023 & 0.722 & 0.0841 \\
\hline Treatment & 17 & 0.026 & 0.1043 & 656.438 & 0.0001 & 1.972 & 0.0001 \\
\hline Error & 51 & 0.016 & & 84.883 & & 0.308 & \\
\hline
\end{tabular}

DAT, days after treatment. *In Ohio, $9.16 \mathrm{~kg}$ quinclorac $\mathrm{ha}^{-1}+1.75 \mathrm{~L}$ methylated seed oil-ha-1 was applied on 24 Jun 2020 with average crabgrass was $24 \%$ plot area covered; the majority of crabgrass was at the fourleaf to one tiller stage; ${ }^{\circ}$ In Pennsylvania, $9.16 \mathrm{~kg}$ quinclorac.ha ${ }^{-1}+1.75 \mathrm{~L}$ methylated seed oil-ha ${ }^{-1}$ was applied on 25 Jun 2020 with average crabgrass was $37 \%$ plot area covered; the majority of crabgrass was at the fourleaf to one tiller stage. \#Percent control calculated from plot ratings data as: [(untreated - treated)/(untreated)] × 100. ^^Analysis of variance of data conducted with Agricultural Research Manager (GDM Solutions, Brookings, South Dakota, USA),

Table 3. Postemergence herbicide crabgrass (Digitaria sp.) efficacy as influenced by spray droplet size from field studies in Wooster, Ohio, USA, and Reading, Pennsylvania, USA, 2020.

\begin{tabular}{|c|c|c|c|c|c|c|}
\hline Spray nozzle and droplet size\# & $\begin{array}{c}24 \text { Jun } \\
\text { (0 DAT) } \\
\% \text { plot }\end{array}$ & $\begin{array}{l}\text { Ohio* } \\
23 \text { Aug } \\
\text { (60 DAT) } \\
\text { covered }\end{array}$ & $\begin{array}{l}23 \text { Aug } \\
\begin{array}{l}(60 \text { DAT })^{\wedge} \\
\% \text { control }\end{array}\end{array}$ & $\begin{array}{l}25 \text { Jun } \\
\text { (0 DAT) } \\
\% \text { plo }\end{array}$ & $\begin{array}{l}24 \text { Aug } \\
\text { ( } 60 \text { DAT) } \\
\text { vered }\end{array}$ & $\begin{array}{l}24 \text { Aug } \\
\text { (60 DAT) } \\
\% \text { control }\end{array}$ \\
\hline Delavan Raindrop 1/4 UC & $16^{\mathrm{a}}$ & $2^{\mathrm{a}}$ & $95^{\mathrm{bc}}$ & $24^{\mathrm{a}}$ & $31^{\mathrm{bc}}$ & $63^{\mathrm{bc}}$ \\
\hline TurfJect 1/4TTJO4 EC & $38^{\mathrm{a}}$ & $7^{\mathrm{a}}$ & $83^{b}$ & $38^{\mathrm{a}}$ & $24^{\mathrm{abc}}$ & $71^{\mathrm{bc}}$ \\
\hline Air Induction AA8004 VC & $31^{\mathrm{a}}$ & $<1^{\mathrm{a}}$ & $98 \mathrm{c}$ & $21^{\mathrm{a}}$ & $12^{\mathrm{a}}$ & $86^{c}$ \\
\hline XR TeeJet 8015 VC & $23^{\mathrm{a}}$ & $<1^{\mathrm{a}}$ & $98 \mathrm{c}$ & $40^{\mathrm{a}}$ & $17^{\mathrm{ab}}$ & $80^{\mathrm{bc}}$ \\
\hline XR TeeJet $8008 \mathrm{C}$ & $27^{\mathrm{a}}$ & $<1^{\mathrm{a}}$ & $98^{\mathrm{c}}$ & $40^{\mathrm{a}}$ & $20^{\mathrm{abc}}$ & $76^{\mathrm{bc}}$ \\
\hline GreenLeaf TDAD04 C & $20^{\mathrm{a}}$ & $2^{\mathrm{a}}$ & $95^{\mathrm{bc}}$ & $43^{\mathrm{a}}$ & $21^{\mathrm{abc}}$ & $75^{\mathrm{bc}}$ \\
\hline XR TeeJet $8004 \mathrm{M}$ & $14^{\mathrm{a}}$ & $<1^{\mathrm{a}}$ & $98^{\mathrm{c}}$ & $45^{\mathrm{a}}$ & $21^{\mathrm{abc}}$ & $75^{\mathrm{bc}}$ \\
\hline XR TeeJet $8003 \mathrm{~F}$ & $18^{\mathrm{a}}$ & $<1^{\mathrm{a}}$ & $98^{\mathrm{c}}$ & $38^{\mathrm{a}}$ & $35^{\mathrm{c}}$ & $58^{\mathrm{b}}$ \\
\hline Untreated & $28^{\mathrm{a}}$ & $41^{\mathrm{b}}$ & $0^{\mathrm{a}}$ & $40^{\mathrm{a}}$ & $84^{\mathrm{d}}$ & $0^{\mathrm{a}}$ \\
\hline
\end{tabular}

DAT, days after treatment. *In Ohio, $9.16 \mathrm{~kg}$ quinclorac.ha ${ }^{-1}+1.75 \mathrm{~L}$ methylated seed oil·ha ${ }^{-1}$ was applied on 24 Jun 2020 with average crabgrass was $24 \%$ plot area covered; majority of crabgrass was at the four-leaf to one tiller stage. ${ }^{\circ}$ In Pennsylvania, $9.16 \mathrm{~kg}$ quinclorach ha ${ }^{-1}+1.75 \mathrm{~L}$ methylated seed oil-ha- ${ }^{-1}$ was applied on 25 Jun 2020 with average crabgrass was $37 \%$ plot area covered; majority of crabgrass was at the four-leaf to one tiller stage. \#Spray nozzle types, spray droplet sizes, and spray patterns: Delavan Raindrop 1/4; UC (ultra coarse) = volume mean diameter (VMD) > 650 $\mu \mathrm{m}$; hollow cone spray pattern; TurfJet 1/4TTJO4; EC

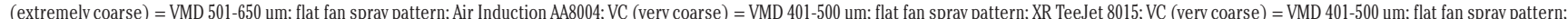
XR TeeJet 8008; C (coarse) = VMD 326-400 $\mu$ m; flat fan spray pattern; GreenLeaf TDAD04; C (coarse) = VMD 326-400 $\mu$ m; dual flat fan spray pattern; XR TeeJet 8004; M (medium) = VMD = 226-325 $\mu$ m; flat fan spray pattern; XR TeeJet $8003 ; \mathrm{M}$ (medium) $=\mathrm{VMD}=145-225 \mu \mathrm{m}$; flat fan spray pattern. ${ }^{\wedge}$ Percent control calculated from plot ratings data as: [(untreated - treated) $/($ untreated) $] \times 100$. a-dTreatment means followed by the same letter are not statistically different according to Fisher's protected least significance difference test at $\mathrm{P} \leq 0.05$. 
extremely coarse, coarse, or medium spray droplets resulted in 20 to $24 \%$ plot area covered with crabgrass (Table 3 ). However, no significant differences were detected when comparing data from plots treated from nozzles that produced extremely coarse, coarse, or medium spray droplets (Table 3).

Best crabgrass control at 60 DAT was observed in plots treated from nozzles that produce very coarse spray droplets at 80 to $86 \%$, followed by extremely coarse, coarse, or medium spray droplets at 71 to $76 \%$ (Table 3 ). Poorest control was observed in plots treated from nozzles that produce ultra coarse or fine spray droplets at 58 to $63 \%$ (Table 3 ). As observed in the field site located in Ohio, no turfgrass injury or phytotoxicity was observed from the herbicide application during the Pennsylvania study.

\section{Discussion}

It is conceivable for turfgrass sites in Ohio with a low crabgrass population of $<50 \%$ plot area covered, one single postemergence quinclorac herbicide application could potentially achieve acceptable control ( $\geq 90 \%$ control) as delivered from a spray nozzle that produces spray droplet sizes ranging from ultra coarse (Delavan Raindrop 1/4) to fine (XR TeeJet 8003). Under heavy crabgrass pressure of $>50 \%$ plot area covered in Pennsylvania, achieving $\geq 90 \%$ crabgrass control would be most desired and acceptable; however, 75 to $89 \%$ control would be considered marginally acceptable to the turfgrass practitioner (Watschke et al., 2013). At the Pennsylvania site, no significant differences were detected when comparing percent crabgrass control in plots treated from nozzles that produced extremely coarse (TurfJet 1/4TTJO4), very coarse (Air Induction AA8004, XR TeeJet 8015), coarse (XR TeeJet 8008, GreenLeaf TDAD04), or medium (XR TeeJet 8004) spray droplets, and all produced a marginally acceptable 71 to $86 \%$ crabgrass control. Also, at the Pennsylvania site, unacceptable 58 to $63 \%$ crabgrass control was observed in plots treated from nozzles that produced ultra coarse (Delavan Raindrop 1/4) to fine (XR TeeJet 8003) spray droplets.

Therefore, in turfgrass sites with a heavy crabgrass population and emergence pressure ( $\geq 50 \%$ plot area covered), one single postemergence quinclorac herbicide application could be maximized by using a spray nozzle that produces a very coarse (Air Induction AA8004, XR TeeJet 8015), coarse (XR TeeJet 8008, GreenLeaf TDAD04), or medium (XR TeeJet 8004) spray droplet size in a flat fan spray pattern. Spray nozzles that produce ultra coarse (Delavan Raindrop 1/4), and extremely coarse (TurfJet 1/4TTJO4) spray droplets have a much larger or 'raindrop' droplet size that is less prone to drift, but coverage on a turfgrass stand is poor, especially from a hollow cone spray pattern (Fidanza et al., 2009a, 2009b). On the other hand, a nozzle that produces fine spray (XR TeeJet 8003 ) droplets conceivably provides better surface coverage, but those smaller droplets are easily prone to drift and thus could cause the herbicide to move into non-target areas.

The ability to achieve acceptable postemergence crabgrass control from quinclorac delivered at a water carrier volume of 407 $\mathrm{L} \cdot \mathrm{ha}^{-1}$ also is worth noting. In the USA, turfgrass industry practitioners typically apply herbicides, fungicides, and other plant and soil health products at one-gallon water carrier $1000 \mathrm{ft}^{-2}$, which equates to $407 \mathrm{~L}$ water carrier $\mathrm{ha}^{-1}$ (Fidanza et al., 2009a; Watschke et al., 2013). This amount of water carrier affords the turfgrass manager the ability to essentially cover more surface area with application equipment due to less downtime on otherwise multiple spray tank refills with higher water carrier volumes
(McCarty et al., 2005). This represents time and financial savings and could be an incentive for turfgrass managers to improve the performance of their pesticide and product spray equipment through water carrier volume and spray nozzle selection.

\section{Conclusions}

These are the first studies to evaluate the potential effects of spray nozzles to optimize postemergence crabgrass control in turfgrass from the quinclorac herbicide. In the Ohio study, crabgrass was treated with a postemergence application of quinclorac when crabgrass was at the three to four-leaf growth stage and at the fourleaf to one tiller growth stage in the Pennsylvania study. Quinclorac is more efficacious when applied to younger crabgrass smaller than the two tiller growth stage or to mature crabgrass larger than the four tiller growth stage. Therefore, turfgrass managers must be vigilant about timing a postemergence quinclorac application during those favourable crabgrass growth stages.

Overall, results from these Ohio and Pennsylvania studies support the practice to implement an adequately timed single postemergence quinclorac application using a spray nozzle that produces an extremely coarse, very coarse, or medium spray droplet size in a flat fan spray pattern. There was some variation with crabgrass population and pressure between the two study sites, and therefore further collaborative research efforts are needed to aid with developing sustainable weed control recommendations for precision turfgrass management. The selection of proper spray nozzle type that delivers the optimum spray droplet spectra is an important strategy to improve the efficiency of postemergence crabgrass herbicide applications and minimize any potential environmental impacts related to spray drift.

\section{References}

ASABE, 2009. Spray nozzle classification by droplet spectra. American Society of Agricultural and Biological Engineers (ASABE), St. Joseph, MI, USA.

Berghaus R, Wuerzer B, 1989. Uptake, translocation and metabolism of quinclorac (BAS 514H) in rice and barnyard grass. pp 133-139 in Proc. of 12th Asian-Pacific Weed Science Society Conference, Taipei, Taiwan.

Brosnan JT, Breeden GK, Vargas JJ, 2014. Influence of simulated rainfall on large crabrass control with two quinclorac-containing herbicides. Appl. Turfg. Sci. 11:1-3.

Chism WJ, Bingham SW, 1991. Postmergence control of large crabgrass (Digitaria sanguinalis) with herbicides. Weed Science 39:62-6.

Contiero RL, Biffe DF, Constantin J, De Oliveria Júnior RS, Braz GBP, Lucio FR, Schleier JJ. 2016. Effects of nozzle types and 2,4-D formulations on spray deposition. J. Environ. Sci. Health 51:888-93.

Creech CF, Henry RS, Fritz, BK, Kruger GR, 2015. Influence of herbicide active ingredient, nozzle type, orifice size, spray pressure, and carrier volume rate on spray droplet size characteristics. Weed Technol. 29:298-310.

Dernoeden PH, Bigelow CA, Kaminski JE, Krouse JM, 2003. Smooth crabgrass control in perennial ryegrass and creeping bentgrass tolerance to quinclorac. HortSci. 38:607-12.

Fidanza MA, Dernoeden PH, Zhang M, 1996. Degree-days for 
predicting smooth crabgrass emergence in cool-season turf. Crop Sci. 36:990-6.

Fidanza MA, Kaminski JE, Agnew ML, Shepard D, 2009a. Evaluation of water droplet size and water-carrier volume on fungicide performance for anthracnose control on annual bluegrass. Int. Turfg. Soc. Res. J. 11:195-205.

Fidanza MA, Gregos JS, Aynardi B, Hudson D, 2009b. Evaluation of fungicides and water-carrier droplet size for dollar spot control in creeping bentgrass, 2006. Plant Dis. Manage. Rep. Report 3:T064.

Grella M, Marucco P, Balafoutis AT, Balsari P, 2020. Spray drift generated in vineyard during under-row weed control and suckering: evaluation of direct and indirect drift-reducing techniques. Sustainability 12:5068.

Grossmann K, Kwiatkowski J, 1993. Selective induction of ethylene and cyanide biosynthesis appears to be involved in the selectivity of the herbicide quinclorac between rice and barnyard grass. J. Plant Physiol. 142:457-66.

Grossman K, 1998. Quinclorac belongs to a new class of highly selective auxin herbicides. Weed Sci. 63:707-16.

Kalsing A, Rossi CVS, Lucio FR, Zobiole LHS, da Cunha LCV, Minozzi GB, 2018. Effect of formulations and spray nozzles on 2,4-D spray drift under field conditions. Weed Technol. 32:379-84.

Kaminsk JE, Fidanza MA, 2009. Dollar spot severity as influenced by fungicide mode of activity and spray nozzle. HortSci. 44:1762-6.

Koo SJ, Kwon YW, Cho KY, 1991. Differences in selectivity and physiological effects of quinclorac between rice and barnyard grass compared with 2,4-D. pp 103-111 in Proc. of the 13th Asian-Pacific Weed Society Conference, Jakarta, Indonesia.
Koo SJ, Neal JC, DiTomaso JM, 1997. Mechanism of action and selectivity of Quinclorac in grass roots. Pest. Biochem. Physiol. 57:44-53.

Lake JR, 1977. The effect of drop size and velocity on the performance of agricultural sprays. Pest. Sci. 8:515-20.

Martin DP, Sullivan JJ, 1996. Influence of annual herbicide applications and the environment on smooth crabgrass control. In: Proceedings of the Northeastern Weed Science Society 50:114.

McCarty LB, Murphy T, Whitwell T, Yelverton F, 2005. Turfgrass weeds. pp 663-703 in McCarty LB (Ed.), Best golf course management practices. $2^{\text {nd }}$ ed. Prentice-hall, Upper Saddle River, NJ, USA.

Mead R, Curnow RN, Hasted, AM, 2003. Statistical methods in agriculture and experimental biology, 3rd ed. CRC Press, Boca Raton, FL, USA.

Johnson BJ, 1994. Influence of dates and frequency of Drive treatments on large crabgrass control in tall fescue turf. J. Environ. Hortic. 12:83-6.

Senseman SA, 2007. Herbicide handbook. Weed Science Society of America, Lawrence, KS, USA.

Stainier C, Destain M-F, Schiffers B, Lebeau F, 2006. Droplet size spectra and drift effect on two phenmedipham formulations and four adjuvants mextures. Crop Prot. 25:1238-43.

Steinke K, Stier J, 2002. Tolerance of Supina bluegrass to pre- and postemergence herbicides. J. Environ. Hortic. 20:118-21.

Watschke TL, Dernoeden PH, Shetlar DJ, 2013. Managing turfgrass pests. $2^{\text {nd }}$ ed. CRC Press, Boca Raton, FL, USA.

Woznica Z, Nalewaja J, Messersmith CG, Milkowski P, 2003. Quinclorac efficacy as affected by adjuvants and spray carrier water. Weed Technol. 17:582-8. 